OPEN ACCESS

Edited by:

Marzena Helena Zajac,

University of Agriculture in

Krakow, Poland

Reviewed by:

Ana Kaić

University of Zagreb, Croatia

Klaus G. Grunert,

Aarhus University, Denmark

*Correspondence:

Gesa Busch

gesa.busch@agr.uni-goettingen.de

Specialty section:

This article was submitted to

Product Quality,

a section of the journal

Frontiers in Animal Science

Received: 18 March 2021

Accepted: 10 June 2021

Published: 05 July 2021

Citation:

Escobedo del Bosque Cl, Risius A,

Spiller $A$ and Busch G (2021)

Consumers' Opinions and Expectations of an "Ideal Chicken

Farm" and Their Willingness to Purchase a Whole Chicken From This Farm. Front. Anim. Sci. 2:682477. doi: 10.3389/fanim.2021.682477

\section{Consumers' Opinions and Expectations of an "Ideal Chicken Farm" and Their Willingness to Purchase a Whole Chicken From This Farm}

\section{Cynthia I. Escobedo del Bosque, Antje Risius, Achim Spiller and Gesa Busch*}

Department of Agricultural Economics and Rural Development, Marketing for Food and Agricultural Products, University of Göttingen, Göttingen, Germany

As poultry production and consumption have increased in the last decade, so have consumers' concerns about intensified production methods and the impacts they have on animal welfare. At the same time, poultry consumption has increased and enjoys great popularity. Also, a shift in consumers' consumption behavior can be observed as nowadays most consumers purchase chicken cuts, especially breast filets, rather than whole animals, mostly due to convenience and taste. Although consumer concerns have increased, market shares of alternative poultry products, i.e., those that are produced under higher standards compared to conventional products, remain comparably low. One of the main reasons are the large differences in prices. The higher prices for alternative chicken products such as organic result partly from increased production costs on farm level. Besides, consumer preferences for chicken cuts intensify cost differences. While alternative chicken breasts (e.g., organically produced) might be valued by some consumers, other cuts such as wings or thighs are not and are therefore sent into the conventional market. In these cases, the breasts need to remunerate all additional costs. Analyzing consumers' concerns about production methods and learning about consumers' obstacles to buy whole chickens might offer farmers greater possibilities to succeed in alternative markets. Therefore, the purpose of this study was to gain insights into consumers' chicken consumption behaviors, how consumers imagine an ideal chicken farm and whether they would be willing to purchase a whole chicken from this ideal farm. Three focus group discussions (total $n=30$ ) with German consumers were held online in June 2020. The results show that participants associate the ideal chicken farm with four main characteristics: good husbandry system, positive economic impact for the farmer, high transparency, and proximate location of the farm in the same geographical region. However, willingness to purchase a whole chicken, even from the ideal farm, remains low due to mainly convenience reasons and daily routines.

Keywords: animal welfare, poultry production, consumer preference, whole chicken, chicken cuts, focus groups 


\section{INTRODUCTION}

The poultry meat sector has grown worldwide for years, focused on indoor environments and automated production systems and processes (Fraser, 2008). In Germany, more than 620 million broilers have been slaughtered in 2019 (Statistisches Bundesamt, 2021). As poultry production grows, worldwide consumption of poultry meat also rises. In Germany, although meat consumption has decreased $\sim 2.2 \mathrm{~kg}$ per capita between 2009 and 2019 (Statista, 2020), poultry consumption has increased by $4.12 \mathrm{~kg}$ per capita in the last decade (Bundesinformationszentrum Landwirtschaft, 2020). This increase in poultry consumption has been related to consumers' association of this type of meat with a healthier diet (less fat content) when compared to other types of meat, particularly red meat (Kennedy et al., 2004; Spiller et al., 2010).

In production, also animal genetics changed and chickens have been selected based on their performance to obtain a greater muscular growth in a short period of time. Before the industrialization of poultry production took place, a broiler (i.e., chicken for meat production) needed around 120 days to reach a weight of $1.5 \mathrm{~kg}$ while nowadays this is achieved in 30 days only [Bundesanstalt für Landwirtschaft und Ernährung (BLE), 2020].

Moreover, with these intensified production schemes farm structures changed. The number of small poultry farms $(<10,000$ animals) in Germany decreased significantly from 1999 to 2016 while the number of big poultry farms ( $>50,000$ animals) increased [Bundesanstalt für Landwirtschaft und Ernährung (BLE), 2020]. These big farms account today for $80 \%$ of all broilers produced in Germany [Bundesanstalt für Landwirtschaft und Ernährung (BLE), 2020]. However, along with these production schemes, public criticism, and concerns toward farm animal welfare in these systems have grown (Vanhonacker et al., 2008; Martelli, 2009; Nocella et al., 2010; De Jonge and van Trijp, 2013), particularly for broiler production and laying hens (Verbeke and Viaene, 2000; Martelli, 2009; Vanhonacker and Verbeke, 2009; Heng et al., 2013). Among the concerns related to the welfare of broilers are high stocking densities in barns (Halle and Sandilands, 2006), a lack of outdoor access (Busch and Spiller, 2018), and leg weakness due to the lack of activity (Bessel, 2006). In laying hens, the killing of day-old male chicks (Brümmer et al., 2017; Busse et al., 2019), and beak trimming (Heng et al., 2013) are additional sources of concern. Further, the use of antibiotics in animal production is negatively perceived by consumers due to their association with antibiotic resistances and residuals causing health problems in humans (Bernard et al., 2005; Yang et al., 2009; Busch et al., 2020).

As the term "animal welfare" has become increasingly debated by the public (Deemer and Lobao, 2011; Lagerkvist and Hess, 2011) and public criticism and concerns regarding the abovementioned topics have increased, it is necessary to understand what regular consumers (i.e., not experts on the topic) consider ideal characteristics of a farm where chickens are reared for human consumption. Although literature shows that animal welfare and type of husbandry system are important attributes for consumers (Tonsor et al., 2009; Vanhonacker and Verbeke, 2014), it is still unknown whether other characteristics are also of relevance to consumers when imagining an "ideal" production method. Although there has been research related to ideal pig (Sato et al., 2017), beef (Kühl et al., 2020), and dairy (Cardoso et al., 2016) farms, to the best of our knowledge there is still a gap regarding chicken farms.

Consumers buying decisions for chicken meat are impacted by several aspects, depending on the information available. Price is certainly among the most important attributes when making buying decisions for meat (Clark et al., 2017; Escobedo del Bosque et al., 2021) but animal welfare attributes are of importance, too. Increased willingness-to-pay for broiler chicken with higher welfare levels is generally given but is lower compared to other animal products such as dairy (Clark et al., 2017). People with higher levels of animal welfare concerns have found to eat less animal products and to pay more attention to welfare labels when buying animal products (Clark et al., 2016). Feed and product origin also influence buying decisions in broiler chicken and are of higher importance compared to breeds (Escobedo del Bosque et al., 2021).

Besides animal welfare concerns and an increase in consumption quantity, the intensive production methods of the poultry industry also allowed for a change in consumers' consumption behavior of poultry. Nowadays, it is possible for consumers to purchase only those cuts which they desire, e.g., breast filets, instead of whole animals. This increasing trend of purchasing specific chicken cuts (e.g., breast filets, thighs) (Birzele and Stetter, 2018) occurs since many consumers see convenience as the most important motive for purchasing specific cuts rather than a whole chicken (Kennedy et al., 2004; Ripoll et al., 2015). Additionally, consumers usually try to avoid associating meat with an animal (Kubberød et al., 2002) in order to feel less guilt (Te Velde et al., 2002; Hopkins and Dacey, 2008) or disgust (Kubberød et al., 2002; Hamilton, 2006; Hopkins and Dacey, 2008). Te Velde et al. (2002) suggest that the unrecognizability of the cuts (e.g., breast filets cannot be as easily recognized as a part of a chicken compared to a whole carcass) also influences the preference for cuts. Nonetheless, the changed genetics and the trend of purchasing only cuts has contributed to a decrease in the number of whole animals being sold (Birzele and Stetter, 2018) and therefore reducing the market segment of whole chicken consumption, which also impacts the production side. Consumers' increasing preference for chicken cuts also led to a shift from "short" (i.e., rearing for $\sim 33$ days to achieve a weight of $1.5 \mathrm{~kg}$ ) to "heavy" (i.e., rearing for $\sim 40$ days to achieve a weight of $2 \mathrm{~kg}$ ) fattening production methods in order to obtain larger and heavier cuts, particularly breasts (Bundschuh and Henning, 2016). Additionally, those cuts that are not consumed in European countries (i.e., wings, thighs, feet, organs) are exported to countries in Africa (e.g., South Africa, Benin, Ghana) and Asia (e.g., Saudi Arabia, Philippines, Hong Kong) (Bundschuh and Henning, 2016) often at low prices (Fourie, 2013; Banson et al., 2015; Bioland, 2020). For small producers of alternative markets in Germany, these developments are challenging. For them, exporting cuts is not economically viable. Selling whole chickens is therefore often an economic decision that is contrasting current consumer trends and challenging small and alternative production with e.g., increased farm animal 
welfare. The topic of consumers' willingness to purchase a whole chicken as well as the advantages and disadvantages of this product from consumers' perspectives has not been studied, to the best of our knowledge. Especially in combination with linking the consumption behavior to the impacts on the famer and the animals.

Since most consumers' knowledge about production systems in the poultry industry is limited (Erian and Phillips, 2017), the aim of this study was 2-fold: (1) to gain insights into how an ideal production of chicken meat looks like from a consumers point of view; and, since it is known that consumers generally prefer cuts our aim was also (2) to assess the potential for marketing whole animals vs. cuts if the whole animal comes from such an ideal farm. The results of this study help understand consumer trade-offs between convenient consumption habits and support for preferred production methods. It indicates whether, and to what extent, consumers are willing to change consumption and preparation habits for the sake of production methods and farms that are in line with their values. In addition, results are relevant to chicken farmers in alternative (e.g., organic or animal welfare) markets in order to better understand what consumers expect from their practices and adapt these to their strategies in order to make chicken production more diverse and sustainable.

\section{MATERIALS AND METHODS}

To generate information addressing our research questions, we gathered qualitative data through online focus groups. As defined by Morgan (1996), focus groups are a research method to collect information on a preset topic through interactions in a group. According to this definition, focus groups have three main characteristics: collecting data, interaction in a group as source of data and an active role of the researcher in creating the group discussions. Focus groups allow creating an almost natural atmosphere that resembles a conversation setting with different opinions (Lamnek, 2005). This difference in opinions also allows participants to respond to and discuss with other participants and therefore generating further insights in the topic and reflect own views. As we did not know in advance all possible aspects that might contribute to an "ideal" broiler farm from a consumers' point of view as well as the drivers of consumer behavior regarding chicken cuts, we decided to choose focus groups as research mode. In addition to this exploratory approach we added some confirmatory elements in the focus group protocols for those cases in which respondents do not come up with topics for discussion by themselves.

In this study, all participants gave informed consent to take part in the study before the discussions started. This study was conducted in accordance with the Declaration of Helsinki, and the protocol including the leading interview questions for the focus groups was approved by the Ethics Committee of the University of Göttingen before data collection.

Three focus group discussions with German residents were held online in June 2020, using a virtual meeting room with audio and video sequences. Each discussion was scheduled for $90 \mathrm{~min}$ and moderated by a professional facilitator. Participants were recruited through an agency (Forester\&Thelen Teststudio $\mathrm{GmbH}$ ) in Hanover, Germany. The prerequisites for taking part in the discussions were consuming chicken meat at least once a month, consuming organic animal products and animal products with an animal welfare label at least once every 2 weeks or being responsible for cooking chicken for the family. The latter was the case for one of the participants in the group discussions (vegetarian that purchases and cooks chicken for the family), while all others were chicken eaters themselves. The age range for participants was set from 25 to 70 years. In each focus group discussion, 10 participants that live in Hanover, a city with $\sim 500,000$ inhabitants in Northern Germany (and its suburban area) took part. Hanover was selected for the discussion groups as it is the capital of Lower Saxony, the state with the highest poultry production in Germany.

Accordingly, the questioning order was semi-structured in order to stay flexible within the discussion but also to have comparable results (Lamnek, 2005). The moderator followed the script of questions (see Supplementary Table 1) which was divided in five main parts and started with (1) a warm-up phase in which the rules for the discussion were explained and each participant introduced him/herself to the group $(10 \mathrm{~min})$. Next, in order to introduce participants to the topic of preferences for chicken meat, participants were asked in part (2) to describe their buying behavior of chicken meat (frequencies, point of purchases and determinants of buying decisions) and to rank the attributes that are of importance when buying chicken meat (20 $\mathrm{min})$. These results will show a first glance at attributes that consumers value when purchasing chicken meat. Therefore, we then centered the discussion on our main research focus in parts 3 and 4. In part (3), participants were asked to describe an ideal chicken farm, according to their expectations. Included were questions about how relevant the farm is for consumers when purchasing chicken meat and which information about the farm would be wished to encounter at the point of sale (30 min). Part (4) of the focus group discussion was dedicated to the question whether participants prefer buying a whole chicken or cuts and for what occasions they buy each of these. In addition, participants were asked whether they would accept buying whole animals that originate from the ideal farm that they described before and how they rate the success of the approach of marketing whole animals. Advantages and disadvantages of marketing whole animals vs. cuts were discussed. Finally, the group discussions ended with (5) a closing question in which participants were asked to comment on the statement of eating less but better meat $(25 \mathrm{~min})$ followed by a summary and feedback section (5 min).

The discussions were recorded and transcribed by the recruiting agency and facilitated to the researchers. The transcripts were then revised and compared to the audio by two researchers independently. Next, the transcripts were analyzed following Knodel (1993) in two steps: (1) organizing and subdividing the data into segments: in this step, the collected data were looked at to determine where each topic started and ended; next, the data was divided into the four main questions asked in this study and (2) coding the material by determining criteria for converting it into analytically useful data. The coding of the 
transcripts was done in the following way (based on Knodel, 1993):

1. Development of codes that corresponded to each item in the discussion guideline: numerical codes were assigned to each research topic: 1 = "determinants of purchase," $2=$ "ideal chicken farm," $3=$ "whole animal vs. cuts," and $4=$ "less but better meat." For each of these four major topics, subtopics were identified and statements were classified accordingly. For example, the topic of "whole chickens" was coded 3.1 and "cuts" was coded as 3.2 since they belonged to the topic coded with 3 .

2. Creation of additional codes for topics that arose and were of special interest for the researchers: for instance, topics such as missing information from chicken meat packages or ideas on how to market whole chickens were mentioned. These were then allocated under a major topic and then coded differently than the subtopics included in the guidelines. For instance, "missing information" was coded 1.A as a subtopic of determinants of purchase (code 1).

3. Development of non-substantive codes that helped in the writing phase: statements that could be used as illustrative quotations when reporting the results of the study were marked with asterisks and italics font while subtopics or additional topics had numerical coding.

The coding of the material was done by two researchers independently, and then themes were compared and adjusted. Since different topics and subtopics were covered in this study, the analysis was done individually for each major category.

\section{RESULTS}

A total of 30 participants took part in the group discussions. The average age was 43 years, with the youngest participant being 25 and the oldest 64 . A total of 15 men and 15 women participated and they were equally distributed in each session. In total, Six participants stated that they purchase and consume chicken meat more than once a week, while 13 participants do so only once a week and 11 once every 2 weeks.

\section{Determinants of Purchase}

At the beginning of each group discussion participants shared their purchase criteria regarding chicken meat. Fourteen participants purchased chicken meat in supermarkets 10 in discounter stores while only three participants purchased directly from a farmer, two in a weekly market, one in an organic shop and one purchased chicken meat online. When purchasing chicken meat, $63 \%$ of participants stated to mainly consider the price of the product. However, for some this meant "not the cheapest" product but included also the weighing with some quality criteria. When referring to a quality-price performance it was mentioned that "if the other criteria are met, I buy the cheapest." For $63 \%$ of participants, the type of husbandry system was as important as price Statements such as "having a good conscience" and "if I must eat it, then it (the chicken) should also had run around" were mentioned when referring to the importance of the type of husbandry system.
Further aspects that were of importance at the moment of purchase were: product origin (30\%)-specifically regional origin, freshness (30\%)-particularly the "best-before date," labels (30\%), appearance (23\%)-including color, paleness, leanness, and texture, and preparation (i.e., marinated or "pure") (23\%). Other aspects that were, although less often, mentioned were: type of packaging (13\%), amount of product (e.g., 500 g) (10\%), cut (e.g., breast filets) (7\%), brand $(3 \%)$, sustainability (3\%), age/size of the animal (3\%), and spontaneous decision (3\%).

Nonetheless, $20 \%$ of consumers stated to not find all necessary information they desire on the products at the point of sale. One participant said that "in the counter no answer about origin" could be given, referring to the salesperson not being able to provide information regarding the origin of the animal; two other participants agreed with this specific comment. Similarly, while discussing missing information, one participant mentioned that "feedstuff is missing" or "one can hardly recognize" referring to animal feedstuff. Additionally, when discussing the information on husbandry system labels participants stated "what is behind it?" showing that this type of information is not easily understandable for all consumers. Although the abovementioned attributes were of importance for participants when purchasing chicken meat, additional attributes that might also be of relevance-particularly those which are not mentioned on the product packaging, remain unknown. Therefore, we asked next, what an ideal chicken farm looks like for these participants.

\section{The Ideal Chicken Farm}

The ideal chicken farm, as described by participants in the focus group discussions, has four main characteristics. These categories were built from the different topics mentioned during the discussions. Table 1 shows the topics discussed with regard to the ideal chicken farm and the counts how often the sub-topics have been mentioned by participants.

First of all, when consumers thought of the ideal husbandry system, free-ranging was mentioned by $30 \%$ of participants, while $20 \%$ of participants emphasized the importance of chickens walking on green fields with sufficient space. A smaller number of participants also mentioned "no mass production" (7\%), "nice building" (3\%), as well as the use of mobile chicken housing (7\%) as part of the ideal farm.

Second, they mentioned the economic aspect for the farmer. Participants expected from the ideal chicken farm that the farmer practices circular farming, i.e., that all steps of production, from feed production to slaughtering, are done on the farm. In addition, three participants suggested that ideally the farm produces both, eggs and meat. Similarly, three participants mentioned that in an ideal scenario consumers pay more for the products, resulting in higher prices for the farmers; when referring to this topic one participant stated that farmers "do not participate in the price war and do not go bankrupt."

The third aspect that constituted an ideal chicken farm is transparency of production and species-appropriate conditions for the animals. While 14 participants mentioned transparency as an important part of the ideal farm, only a few gave specific examples of what they expected. For instance, two 
TABLE 1 | Topics and sub-topics built from the group discussions of the "ideal chicken farm."

\begin{tabular}{|c|c|c|}
\hline Topic & Sub-topic & $\begin{array}{l}\text { Number of } \\
\text { mentions }\end{array}$ \\
\hline \multirow[t]{9}{*}{ Husbandry } & Free-range & 9 \\
\hline & Green fields & 6 \\
\hline & Space & 3 \\
\hline & Weather protection & 1 \\
\hline & No mass production & 2 \\
\hline & Large farm & 1 \\
\hline & Nice building & 1 \\
\hline & Mobile housing & 2 \\
\hline & Tents & 1 \\
\hline \multirow[t]{7}{*}{ Economics and production } & Development of the farm & 1 \\
\hline & Pre-ordering of meat & 2 \\
\hline & Idyllic farm & 2 \\
\hline & Cycle farming & 12 \\
\hline & Utilization of everything & 1 \\
\hline & Fair pricing & 3 \\
\hline & Production of egg and meat & 3 \\
\hline \multirow[t]{8}{*}{ Animals and their lives } & Balanced nutrition & 3 \\
\hline & Species-appropriate behavior & 12 \\
\hline & No shredding of chicks & 4 \\
\hline & Animals live longer & 1 \\
\hline & Transparency & 14 \\
\hline & No antibiotics & 2 \\
\hline & No growth hormones & 1 \\
\hline & Antibiotics only when needed & 3 \\
\hline \multirow[t]{3}{*}{ Origin } & From the region & 5 \\
\hline & Regional feedstuff & 8 \\
\hline & Farmers grow their own feedstuff & 2 \\
\hline \multirow[t]{10}{*}{ Definition of regional } & Radius $50 \mathrm{~km}$ & 3 \\
\hline & Lower Saxony & 5 \\
\hline & Region of Hanover & 2 \\
\hline & Under $100 \mathrm{~km}$ & 3 \\
\hline & Germany & 1 \\
\hline & Production not possible everywhere & 1 \\
\hline & Nord Germany & 1 \\
\hline & 200 km & 1 \\
\hline & 300 km & 1 \\
\hline & $200-300$ km & 1 \\
\hline \multirow[t]{4}{*}{ Farm size } & Small & 12 \\
\hline & $\begin{array}{l}\text { Irrelevant if animals have enough } \\
\text { space }\end{array}$ & 7 \\
\hline & Irrelevant & 6 \\
\hline & No mass production & 3 \\
\hline
\end{tabular}

participants stated to want information about the farm with "realistic pictures" on a website and to be accessible through Quick Response (QR) codes on the products. Participants were also interested in seeing how and where the animals are raised; statements such as "petting chickens and feeding them yourself," "know the farm owners, see where the animals live," and "guided tour for children" were mentioned by four participants as ways to see how the farm works. Regarding transparency, two participants also mentioned "where you can see feeding conditions" as an important aspect of the ideal chicken farm. Additionally, two participants wished to know how much space chickens have while 12 of them wanted to see that the animals are reared in a species-appropriate way. The use of antibiotics was mentioned, however the opinion seemed divided into two groups: the first wished no antibiotics in the production at all and the other group agreed with the application of antibiotics only when necessary. With regard to size of the farms, perceptions differed: $40 \%$ of participants clearly expected an ideal farm to be rather small, whereas $23 \%$ stated being indifferent on farm size as long as chickens are kept and treated in a good way or "if there is enough staff and space." For instance, first participant mentioned that even on an ideal farm "there can be 39,000 animals, but in small groups and kept in such a way that they get along."

As a fourth point, participants wanted the ideal farm to be located in their region in order to reduce transportation distances. Additionally, $27 \%$ of participants mentioned that the ideal chicken farm should use regional feedstuff, preferably grown on the same farm. Although most participants were not aware of which type of feedstuff is fed to chickens, $23 \%$ of participants highlighted that the feedstuff should "not be imported," "not come from South America," and "not be genetically modified." The question of what regional production means was also discussed. It was clear that consumers have different ideas: for $30 \%$, regional was measured in a radius of $50,100,200,300 \mathrm{~km}$ around place of residence while for others it meant a city (Hanover) (7\%), a state (Lower Saxony) (17\%), or even a country (Germany) (3\%). As consumers have different ideas about what regional production means, one participant suggested indicating the distance between farm and point of sale on the product, which was supported by other participants in the group.

When consumers were asked to state, if they take all of the above mentioned aspects into account when purchasing chicken meat, only two claimed to do so while 10 stated that they only focus on one or two points (e.g., origin, animal husbandry).

\section{Whole Chicken vs. Cuts}

A higher share of participants (43\%) in the focus groups stated to buy chicken cuts (e.g., breast, thighs, wings) instead of whole chickens. The $33 \%$ of participants who purchase whole chickens stated to do so mainly for special occasions like barbecue, when guests are visiting or when more time for cooking is available (e.g., weekend or holidays). The high time requirement was mentioned by six participants as the main disadvantage associated with the preparation of whole chickens. Additional obstacles of buying whole chickens were the need of "specific tools" such as cutting scissors, the large quantity of chicken meat that needs to be eaten and the problems associated to storing this large amount of meat. Among the advantages of purchasing a whole chicken "less food waste," "better taste," and quality ("I see what I purchase") were mentioned by eight participants.

On the other hand, four participants stated that the main advantage of cooking chicken cuts was also less food waste on the 
household level as well as the ability to cook the desired amount of meat rapidly. Additional advantages such as less workload, less time needed and easy recognition of quality were mentioned by six participants. The main disadvantages of cuts, mentioned by three participants, were seen in more food waste in the chicken industry as well as the lack of sustainability when purchasing only chicken breasts.

When confronted with the idea that the ideal chicken farm only sells whole broilers, the groups' opinions were again divided. Three participants said it was a bad idea. Three participants stated that the "idea is good but I would not do it" and one that it was "unrealistic" since some households consist of only one or two members. On the other hand, five participants thought it was a good idea and would purchase the product; however, three participants who would purchase the whole chicken stated to still prefer buying cuts (i.e., purchasing the whole chicken disassembled).

In order to generate demand for a whole chicken from this ideal farm, three participants stated that if the positive aspects of production (e.g., sustainability, animal welfare, regional production) were highlighted this could be possible. Other ideas that were mentioned to generate demand for this product included: "associate a whole chicken with an occasion, for example a Sunday grill," to reach a compromise by selling half chickens, to sell these whole animals to grillers, "educationexplain good criteria for a whole chicken," to sell in one particular supermarket store and "he must make himself known there" (he refers to the farmer).

Finally, participants discussed under which circumstances their willingness to purchase a whole chicken would increase. Three participants suggested that including recipes on how to prepare the chicken would increase their interest. The idea of farmers offering a "package" with a "perfect meal" (i.e., vegetables to accompany a specific dish) was also suggested by one participant. When asked about purchasing smaller breeds which result in smaller animals three participants thought it was a good idea and could be an option to increase consumer interest since the amount of meat would be less and therefore more adequate for smaller households. However, three others argued against this point by saying "if I have to do the cutting, I prefer to have more," and one mentioned that it is not a good idea if it costs more.

\section{Eating Less but Better Meat?}

Finally, when responding to the statement eating "less but better meat," 13 participants thought this was a good idea, whereas six others asked why not eating "more better meat" or "paying more for meat," denying the reduction component of the statement. The question of what better meat meant was answered with higher quality (20\%), animal friendliness (7\%), and regional production (7\%) as quality indicators by participants.

\section{DISCUSSION}

\section{The Ideal Chicken Farm}

When thinking about the ideal chicken farm, participants in our study mentioned a good husbandry system including free-ranging as an important criterion. This is in line with what others found (Martínez Michel et al., 2011), also holding true for pigs (Weible et al., 2016; Sato et al., 2017) and dairy cows (Cardoso et al., 2016). Outdoor access is often acting as a key indicator for an animal welfare friendly system in the consumers' perception (Busch and Spiller, 2018). Husbandry system has also been mentioned as important for making purchase decisions by participants in the focus groups (together with price). The importance of animal husbandry systems could be a consequence of the negative associations consumers have with animal rearing (Te Velde et al., 2002; Weible et al., 2016), mostly gathered from different sources such as television, newspapers, stories heard from other people, or visiting farms (Te Velde et al., 2002; Tonsor and Olynk, 2011; Weible et al., 2016; Erian and Phillips, 2017). Since consumers' definitions of animal welfare are usually different than farmers' definitions (Te Velde et al., 2002), it is important to understand what consumers expect. Consumers usually focus on housing conditions since these are strongly associated to the ability of animals to express their behavior, resembling their natural environment (Van Poucke et al., 2006; Sato et al., 2017). Consumers usually associate housing conditions to animal welfare (Sato et al., 2017; Vigors, 2019), and when thinking about positive animal welfare they think of small farms with animals living outdoors in a natural environment (Vigors, 2019). However, products of animals with a more animal-friendly husbandry system usually come with a higher price associated to a lower stocking density, more feedstuff needed, more space needed, etc. (Bornett et al., 2003; Lusk and Norwood, 2011). Nonetheless, many consumers state that they are willing to pay a higher price for animal products produces under higher animal welfare standards (Vanhonacker and Verbeke, 2009; Napolitano et al., 2010; Nocella et al., 2010; Clark et al., 2017). Even so, there is still a gap between the attitude (i.e., concern for farm animal welfare) and the actual behavior (i.e., purchasing a product with higher animal welfare standards) (Te Velde et al., 2002; Vanhonacker et al., 2008; Vanhonacker and Verbeke, 2009). This suggests that although many consumers might have concerns about animal welfare and have intentions of purchasing products with higher animal welfare standards, they might actually not purchase the product due to different and diverse reasons, also including the weight of a higher price (De Jonge and van Trijp, 2013). This is discussed as attitude-behavior or consumer-citizen gap (e.g., Ajzen, 2005; Vermeir and Verbeke, 2006). Also farmers have expressed doubt in consumers' and retailers' willingness to pay a fair price that would cover their expenses for implementing higher animal welfare standards (Bock and van Huik, 2007) and participants in the research presented herein valued price as equally important than husbandry system. Price has already been identified as the most important attribute when buying meat by others (Clark et al., 2017). In the focus groups presented herein, price as a purchase determinant did not necessarily mean purchasing the cheapest product but considering the price quality ratio. In the case of broilers, studies reveal that many people are concerned about animal welfare but there is a lower willingness to pay for it compared to e.g., beef (Clark et al., 2017). This challenges the selling of alternative chicken products and emphasizes the 
importance of good communication and available information about product quality.

A lack of information and availability of information on husbandry and welfare conditions is also an important factor that has been mentioned by our study participants and acts as a barrier in buying according to welfare attitudes ad preferences. Only few countries have specific welfare labels or labeling of husbandry systems on products, making it hard for consumers to get information. In Germany, for example, the labeling of husbandry systems on conventional meat has only been introduced by some retailers into the market in 2019. Even in the latter case of Germany, the meaning of such labeling is not necessarily self-explaining for consumers-as it has been stated by study participants.

As part of the ideal chicken farm, participants consider important that farmers are paid fair prices for their products. Other studies have shown that consumers' desire to support (local) farmers (Chambers et al., 2007) and are in favor of paying farmers fair and higher prices for their products (Padel et al., 2010; Busch and Spiller, 2016). Additionally, on an ideal farm they expect farmers to carry out all production steps on farm, including slaughter and feed production. This is rarely the case since protein feedstuff, particularly soy for poultry production, is imported from countries outside the EU [De Visser et al., 2014; Deutscher Bauernverband (DBV), 2016]. Additionally, animals are born in hatcheries and then transported to fattening farms and animals are not slaughtered on farm but rather at a slaughterhouse. Moreover, the slaughter of animals also implicates much more work for farmers and, even more importantly, the need of facilities designed and legally approved for slaughter. Therefore, carrying out all steps of broiler production on farm seems not realistic for the large majority of farmers. A compromise for this could be the use of mobile slaughterhouses as consumers have expressed an interest and a higher willingness to pay for mobile slaughtered animals (Carlsson et al., 2007; Hoeksma et al., 2017).

As urbanization has grown, consumers' distancing from agriculture has also increased (Albersmeier and Spiller, 2008; Böhm et al., 2009; Olynk, 2012). This disconnect from agriculture along with food scandals, have generated a lack of trust in agricultural production systems (Kubberød et al., 2002; Spiller et al., 2010; Berk, 2012). This distancing and lack of trust have increased consumers' demand for transparency in production processes over the last few years (Olynk, 2012). Our results confirm this, as participants indicated transparency as an important part of an ideal chicken farm, particularly regarding how and where the animals are raised. Nowadays consumers can find meat products with labels related to different topics such as: organic and sometimes husbandry systems, regional origin, and animal welfare. Although these labeling schemes have aimed to inform consumers and increase transparency of the production methods (Olynk, 2012), they are not extensively available and, apart from the organic label, well-known. Many consumers do not trust the information, are confused and do not know what each label means, or feel like there is an overload of information (Martelli, 2009; Vanhonacker and Verbeke, 2014). This was also reflected in our discussions, where participants revealed that when purchasing chicken meat, the information available was not always clear to them. Additionally, not all information (e.g., region of production, husbandry system, farm size, animal welfare conditions) is made available, particularly when purchasing meat at the counter. This problem was also mentioned by participants in this study who revealed that when purchasing meat at the counter the employee could not answer questions regarding the animal origin. This suggests the need for a consistent, clearer, and more transparent communication system when marketing such products, including the training of sales persons.

Product origin (i.e., farm location for animal products) is of high importance to many consumers as geographical proximity is usually associated to a high product quality, including freshness and better taste (Chambers et al., 2007; Grebitus et al., 2013; Feldmann and Hamm, 2015). Preference for local agricultural products such as fruits and vegetables and products of animal origin has been previously tested in several studies (Zepeda and Leviten-Reid, 2004; Chambers et al., 2007; Brown et al., 2009; Grebitus et al., 2013; Marcoz et al., 2014). In this study, participants mentioned the preference for regional products in order to reduce transportation distances. The preference for regional products due to the environmental friendliness of the production process, including transportation has also been found in other studies (Brown et al., 2009; Yue and Tong, 2009). Although most consumers were not aware of what chickens eat or where the feedstuff comes from, participants in this study mentioned the use of regional feedstuff as part of the ideal chicken farm's process. However, little is known about consumers' preference for animal feedstuff, including its origin. A few studies (Wägeli et al., 2015; Profeta and Hamm, 2018) show that there is potential for animal products produced with local feed as consumers would be willing to pay more for such products. Although most participants in this study prefer "regional" products, the definition of regional is still very ambiguous as each participant had its own criteria. This difference in perception of what regional entails can be attributed to the lack of an official definition and regulation (Feldmann and Hamm, 2015). Indicating the distance between the farm and point of sale, as suggested by participants in this study, seems like an easy and understandable way for consumers to determine themselves whether they are purchasing a regional product or not. The preference for labeling products with specific distances in miles/kilometers has also been elicited by consumers in Grebitus et al. (2013), although such labeling might be challenging for producers selling into different channels.

\section{Whole Chicken vs. Cuts}

Consumers' readiness to purchase a whole chicken (rather than cuts) from their ideal farm was divided, although it was seen as a good idea in general. Consumers resisting purchasing a whole animal stated that the amount of meat and work was too much for a household with one or two people. Especially when prices are higher for these whole chickens, these consumers will not be willing to switch to buying whole chickens as price play a predominant role in the buying decision (Clark et al., 2017). Ripoll et al. (2015) and Kennedy et al. (2004) found 
that consumers' main motivation to purchase cuts was the convenience of these pieces which is in line with our findings. Participants' interest in a product's convenience shows that consumers' lifestyles play a big role in purchasing behavior, even though they might compromise the "ideal" production method. As participants in this study suggested, the demand for whole chickens from the "ideal chicken farm" could be increased by focusing on promoting the sustainability, animal welfare, and regional production aspects of the products. This might be a good strategy as some consumers exhibit an increased willingness-to-pay for these aspects (Janssen et al., 2016). However, Vanhonacker and Verbeke (2014) suggest that rather than highlighting the benefits of higher welfare products, informing consumers about the current practices and their disadvantages might be a more efficient way to market products. In the case of marketing whole chickens it remains unclear how increased prices would further decrease consumers' acceptance compared to buying the more convenient cuts.

Not all consumers know how to prepare a whole chicken. The inclusion of cooking recipes as well as instructions for cutting the whole chicken (or selling a whole chicken already cut) were seen as good motivators to increase consumer's willingness to purchase a whole chicken. The inclusion of cooking recipes could help farmers to sell their products as a greater involvement in preparing and cooking food usually leads to purchasing local products (Cranfield et al., 2012; Zepeda and Nie, 2012).

Due to the obstacle many consumers have in purchasing a whole animal, an alternative for small-scale farmers could be offering a whole animal but already cut into the different pieces. In this way, consumers can have a whole animal without losing the convenience of individual storage and preparation of individual cuts. This system is currently used by Crowdbutching $\mathrm{GmbH}$, were the animals (e.g., cows, pigs, chickens) are slaughtered only when all pieces have been sold. In the case of chicken meat, their website (http://www.kaufeinhuhn.de) allows consumers to choose from different packages of either cuts (including breast filets, wings, thighs, and drumsticks) or whole animals (mainly used for soups). Others are also using similar systems in solidary agriculture. Although such system implies more work for farmers or slaughterhouses/cutting facilities (slaughter, disassembling/cutting, and packaging), it also provides an opportunity to attract consumers and expand markets.

\section{Eating Less but Better Meat?}

A high consumption, and therefore production, of meat is associated with environmental issues such as high greenhouse gas emissions, water and soil contamination and a loss of biodiversity (Deckers, 2010; De Vries and De Boer, 2010; Lesschen et al., 2011). However, only few consumers have an idea of the environmental impact of meat production and consumption, and they usually underestimate this impact (Macdiarmid et al., 2016; Hartmann and Siegrist, 2017). Accordingly, many consumers are not willing to reduce their meat consumption or substitute meat for other protein sources (Rothgerber, 2012; Macdiarmid et al., 2016; Hartmann and Siegrist, 2017). This behavior is justified with satisfaction-related (e.g., taste, satiety) or health-related (e.g., necessary for strong muscles, need for animal protein) arguments (Rothgerber, 2012; Macdiarmid et al., 2016). This is also reflected in our study, where only a third of participants agreed with the phrase "eat less but better meat," while the other participants questioned why "less meat" and not "more."

\section{CONCLUSIONS}

In this study, eliciting what consumers perceive an ideal chicken farm was the main research goal. Four main aspects could be found to be of importance for many: (1) husbandry systems with much space for the animals including free-ranging, (2) circular farming (all is done on the farm, from fodder production to slaughtering) with adequate remuneration of farmers for their efforts, (3) transparency about good animal conditions for consumers and (4) geographical proximity between place of production and consumption. In summing up these results, the "ideal" chicken farm from a consumer's point of view is quite different from common conventional production systems that usually produce intensively indoors, buy the animal feed that is internationally produced and traded, and sell the products into anonymous markets where consumer cannot easily trace the product back to single farms. Although these mentioned aspects constitute the ideal chicken farm, many participants only take a few attributes into account when making a purchase decision at the point of sale. This finding supports the phenomena frequently discussed as consumer-citizen or attitude-behavior gap. In order to let this gap shrink and to support consumers behaving according to their attitudes, there is a need for improved communication when selling products with improved production methods, especially improved welfare. The information needs to be available in an easy, recognizable and independent way at the point of sale. The strong preference for purchasing cuts instead of whole chickens might be a challenge for producers with high welfare and sustainability standards. In order to get their efforts remunerated, those farmers need to make all information and processes transparent and invest in good communication to highlight the advantages of their products. Nevertheless, market segments for whole chicken, although produced on an "ideal" farm might remain a niche segment.

\section{DATA AVAILABILITY STATEMENT}

The original contributions presented in the study are included in the article/Supplementary Material, further inquiries can be directed to the corresponding author.

\section{AUTHOR CONTRIBUTIONS}

$\mathrm{CB}, \mathrm{AR}, \mathrm{AS}$, and GB: conceptualization and methodology. GB: validation. CB: formal analysis, resources, data curation, and visualization. $\mathrm{CB}, \mathrm{AR}$, and $\mathrm{GB}$ : investigation and writing-review and editing. $\mathrm{CB}$ and $\mathrm{GB}$ : writing-original draft preparation. AS: supervision and funding acquisition. $\mathrm{CB}$ and $\mathrm{AS}$ : project 
administration. All authors have read and agreed to the published version of the manuscript.

\section{FUNDING}

This research was funded by the Lower Saxony Ministry of Science and Culture (Niedersächsisches Ministerium für Wissenschaft und Kultur), Grant Number MWK 11-76251-9930/16. The funders had no role in the design of the study; in the collection, analyses, or interpretation of data; in the writing of the manuscript, or in the decision to publish the results.

\section{REFERENCES}

Ajzen, I. (2005). "Laws of human behavior: symmetry, compatibility, and attitude-behavior correspondence," in Multivariate Research Strategies, eds A. Beauducel, B. Biehl, M. Bosnjak, W. Conrad, G. Schönberger, D. Wagener (Aachen: Shaker Verlag), 3-19.

Albersmeier, F., and Spiller, A. (2008). Supply Chain Reputation in der Fleischwirtschaft. Discussion paper (0811). Goettingen: Department of Agricultural Economics and Rural Development; University of Goettingen. Available online at: https://www.econstor.eu/bitstream/10419/29661/1/ 588532940.pdf

Banson, K. E., Muthusamy, G., and Kondo, E. (2015). The import substituted poultry industry, evidence from Ghana. Int. J. Agric. Forestry 5, 166-175. doi: 10.5923/j.ijaf.20150502.11

Berk, J. (2012). “Technik in der Geflügelhaltung," in Jahrbuch Agrartechnik 2012, ed L. Frerichs (Braunschweig: Institut für mobile Maschinen und Nutzfahrzeuge), 1-9.

Bernard, J. C., Pan, X., and Sirolli, R. (2005). Consumer attitudes towards genetic modification and other possible production attributes for chicken. J. Food Distribution Res. 36, 1-11. doi: 10.22004/ag.econ.27714

Bessel, W. (2006). Welfare of broilers: a review. World's Poultry Sci. J. 62, 455-466. doi: 10.1079/WPS2005108

Bioland (2020). Hühner-Exporte nach Afrika. Esst das ganze Huhn! Available online at: http://www.bio-hennen.de/im-fokus/interviews/detail/article/esstdas-ganze-huhn.html (accessed October 26, 2020)

Birzele, C., and Stetter, B. (2018). Eier und Geflügel. Agrarmärkte. p. 244-271. Landesanstalt für Landwirtschaft; Ernährung und Ländlichen Raum (LEL); Bayerische Landesanstalt für Landwirtschaft (LfL). Available online at: https://www.lfl.bayern.de/mam/cms07/publikationen/daten/schriftenreihe/ agrarmaerkte-2018_lfl-schriftenreihe.pdf

Bock, B. B., and van Huik, M. M. (2007). Animal welfare: the attitudes and behavior of European pig farmers. British Food J. 109, 931-944. doi: 10.1108/00070700710835732

Böhm, J., Albersmeier, A., Spiller, A., and Zühlsdorf, A. (2009). "Zukunftsfaktor gesellschaftliche Akzeptanz: Kommunikation mit der Öffentlichkeit-Mehr als Krisen-PR," in Die Ernährungswirtschaft im Schweinwerferlicht der Öffentlichkeit, eds J. Böhm, F. Albersmeier, and A. Spiller (Lohmar: Eul Verlag), 5-16.

Bornett, H. L. I., Guy, J. H., and Cain, P. J. (2003). Impact of animal welfare on costs and viability of pig production in the UK. J. Agric. Environ. Ethics 26, 163-186. doi: 10.1023/A:1022994131594

Brown, E., Dury, S., and Holdsworth, M. (2009). Motivations of consumers that use local, organic fruit and vegetable box schemes in Central England and Southern France. Appetite 53, 183-188. doi: 10.1016/j.appet.2009. 06.006

Brümmer, N., Christoph-Schulz, I., and Rovers, A. K. (2017). Consumers' perspective on dual-purpose chickens. Proc. Syst. Dyn. Innov. Food Netw. 164-169. doi: 10.18461/ijfsd.v9i5.951

Bundesanstalt für Landwirtschaft und Ernährung (BLE) (2020). Tier. Available online at: https://www.praxis-agrar.de/tier/gefluegel/ gefluegelfleischerzeugung/ (accessed October 2, 2020).

\section{ACKNOWLEDGMENTS}

The authors would like to thank Jürgen von Heyden for his contribution in the analysis of the transcripts. For the publication of this work, we acknowledge support by the Open Access Publication Funds of the Göttingen University.

\section{SUPPLEMENTARY MATERIAL}

The Supplementary Material for this article can be found online at: https://www.frontiersin.org/articles/10.3389/fanim. 2021.682477/full\#supplementary-material

Bundesinformationszentrum Landwirtschaft (2020). Versorgung. Available online at: https://www.bzl-datenzentrum.de/versorgung/versorgungsbilanz-fleischgrafik/ (accessed October 2, 2020).

Bundschuh, R., and Henning, K. (2016). Eier und Geflügel. Agrarmärkte. p. 249-276. Landesanstalt für Entwicklung der Landwirtschaft und der Ländlichen Räume (LEL); Bayerische Landesanstalt für Landwirtschaft (LfL). Available online at: https://www.lfl.bayern.de/mam/cms07/publikationen/ daten/schriftenreihe/agrarmaerkte-2016_lfl-schriftenreihe.pdf

Busch, G., Kassas, B., Palma, M., and Risius, A. (2020). Perceptions of antibiotic use in Germany, Italy and the US. Livestock Sci. 241:104251. doi: 10.1016/j.livsci.2020.104251

Busch, G., and Spiller, A. (2016). Farmer share and fair distribution in food chains from a consumer's perspective. J. Econ. Psychol. 55, 149-158. doi: 10.1016/j.joep.2016.03.007

Busch, G., and Spiller, A. (2018). Pictures in public communication about livestock farming. Anim. Front. 8, 27-33. doi: 10.1093/af/vfx003

Busse, M., Kernecker, M. L., Zscheischler, J., Zoll, F., and Siebert, R. (2019). Ethical concerns in poultry production: a German consumer survey about dual purpose chickens. J. Agric. Environ. Ethics 32, 905-925. doi: 10.1007/s10806-019-09806-y

Cardoso, C. S., Hötzel, M. J., Weary, D. M., Robbins, J. A., and von Keyserlingk, M. A. G. (2016). Imagining the ideal dairy farm. J. Dairy Sci. 99, 1-9. doi: 10.3168/jds.2015-9925

Carlsson, F., Frykblom, P., and Lagerkvist, C. J. (2007). Consumer willingness to pay for farm animal welfare: mobile abattoirs versus transportation to slaughter. European Rev. Agric. Econ. 34, 321-344. doi: 10.1093/erae/ jbm025

Chambers, S., Lobb, A., Butler, L., Harvey, K., and Traill, W. B. (2007). Local, national and imported foods: a qualitative study. Appetite 49, 208-213. doi: 10.1016/j.appet.2007.02.003

Clark, B., Stewart, G., Panzone, L. A., Kyriazakis, I., and Frewer, L. J. (2017). Citizens, consumers and farm animal welfare: a meta-analysis of willingness-to-pay studies. Food Pol. 68, 112-127. doi: 10.1016/j.foodpol.2017. 01.006

Clark, B., Stewart, G. B., Panzone, L. A., Kyriazakis, I., and Frewer, L. J. (2016). A systematic review of public attitudes, perceptions and behaviours towards production diseases associated with farm animal welfare. J. Agric. Environ. Ethics 29, 455-478. doi: 10.1007/s10806-016-9615-x

Cranfield, J., Henson, S., and Blandon, J. (2012). The effect of attitudinal and sociodemographic factors on the likelihood of buying locally produced food. Agribusiness 28, 205-221. doi: 10.1002/agr.21291

De Jonge, J., and van Trijp, H. C. M. (2013). Meeting heterogeneity in consumer demand for animal welfare: a reflection on existing knowledge and implications for the meat sector. J. Agric. Environ. Ethics 26, 629-661. doi: 10.1007/s10806-012-9426-7

De Visser, C., Schreuder, R., and Stoddard, F. (2014). The EU's dependency on soya bean import for the animal feed industry and potential for EU produced alternatives. OCL 24:D407. doi: 10.1051/ocl/2014021

De Vries, M., and De Boer, I. J. M. (2010). Comparing environmental impacts for livestock products: a review of life cycle assessments. Livest. Sci. 128, 1-11. doi: 10.1016/j.livsci.2009.11.007 
Deckers, J. (2010). Should the consumption of farmed animal products be restricted, and if so, by how much? Food Policy 35, 497-503. doi: 10.1016/.j.foodpol.2010.06.003

Deemer, D. R., and Lobao, L. M. (2011). Public concern with animal welfare: religion, politics, and human disadvantage in the food sector. Rural Sociol. 76, 167-196. doi: 10.1111/j.1549-0831.2010.00044.x

Deutscher Bauernverband (DBV) (2016). "Erzeugung und Märkte. Situationsbericht 2016/17," in Trends und Fakten zur Landwirtschaft, eds U. Hemmerling, P. Pascher, and S. Naß (Berlin: Deutscher Bauernverband), 148-193.

Erian, I., and Phillips, C. J. C. (2017). Public understanding and attitudes towards meat chicken production and relations to consumption. Animals 7:20. doi: 10.3390/ani7030020

Escobedo del Bosque, C. I., Spiller, A., and Risius, A. (2021). Who wants chicken? Uncovering consumer preferences for produce of alternative chicken product methods. Sustainability 13:2440. doi: 10.3390/su13052440

Feldmann, C., and Hamm, U. (2015). Consumers'perceptions and preferences for local food: a review. Food Qual. Prefer. 40, 152-164. doi: 10.1016/j.foodqual.2014.09.014

Fourie, H. (2013). Not a Free Lunch: The Implications of Increased Import Tariffs on South Africa's Chicken Market. Econex, Research Note 31. Available online at: https://econex.co.za/wp-content/uploads/2015/04/econex_ researchnote_31.pdf (accessed October 23, 2020).

Fraser, D. (2008). "Animal welfare and the intensification of animal production," in Ethics of Intensification: Agricultural Development and Cultural Change, Vol. 16, ed P. B. Thompson (Rome: FAO), 167-189.

Grebitus, C., Lusk, J. L., and Nayga, R. M. (2013). Effect of distance of transportation on willingness to pay for food. Ecol. Econ. 88, 67-75. doi: 10.1016/j.ecolecon.2013.01.006

Halle, C., and Sandilands, V. (2006). Public Attitudes to the Welfare of Broiler Chickens. Working Papers 45998. Scotland's Rural College; Land Economy and Environment Research Group. Available online at: https://ideas.repec.org/p/ ags/srlewp/45998.html

Hamilton, M. (2006). Disgust reactions to meat among ethically and health motivated vegetarians. Ecol. Food Nutr. 45, 125-158. doi: 10.1080/03670240500530691

Hartmann, C., and Siegrist, M. (2017). Consumer perception and behaviour regarding sustainable protein consumption: a systematic review. Trends Food Sci. Tech. 61, 11-25. doi: 10.1016/j.tifs.2016.12.006

Heng, Y., Peterson, H., and Li, X. (2013). Consumer attitudes towards farmanimal welfare: the case of laying hens. J. Agric. Res. Econ. 38, 418-434. doi: 10.22004/ag.econ.165936

Hoeksma, D. L., Gerritzen, M. A., Lokhorst, A. M., and Poortvliet, P. M. (2017). An extended theory of planned behavior to predict consumers' willingness to buy mobile slaughter unit meat. Meat Sci. 128, 15-23. doi: 10.1016/j.meatsci.2017.01.011

Hopkins, P. D., and Dacey, A. (2008). Vegetarian meat: could technology save animals and satisfy meat eaters? J. Agric. Environ. Ethics 21, 579-596. doi: 10.1007/s10806-008-9110-0

Janssen, M., Rödiger, M., and Hamm, U. (2016). Labels for animal husbandry systems meet consumer preferences: results from a meta-analysis of consumer studies. J. Agric. Environ. Ethics 29, 1071-1100. doi: 10.1007/s10806-0169647-2

Kennedy, O. B., Stewart-Knox, B. J., Mitchell, P. C., and Thurnham, D. I. (2004). Consumer perceptions of poultry meat: a qualitative analysis. Nutr. Food Sci. 34, 122-129. doi: 10.1108/00346650410536746

Knodel, J. (1993). "The design and analysis of focus group studies," in Successful Focus Groups. Advancing the State of the Art, ed D. L. Morgan (Newbury Park, CA: SAGE Publications), 35-50.

Kubberød, E., Ueland, Ø., Tronstad, Å., and Risvik, E. (2002). Attitude towards meat and meat-eating among adolescents in Norway: a qualitative study. Appetite 38, 53-62. doi: 10.1006/appe.2002.0458

Kühl, S., Busch, G., and Gauly, M. (2020). How should beef be produced? Consumer expectations and views on local beef production in South Tyrol (Italy). British Food J. 123, 1578-1595. doi: 10.1108/BFJ-07-2020-0571

Lagerkvist, C. J., and Hess, S. (2011). A meta-analysis of consumer willingness to pay for farm animal welfare. European Rev. Agric. Econ. 38, 55-78. doi: $10.1093 /$ erae/jbq043
Lamnek, S. (2005). Gruppendiskussion. Theorie und Praxis, 2nd Edn. Stuttgart: UTB.

Lesschen, J. P., van den Berg, M., Westhoek, H. J., Witzke, H. P., and Oenema, O. (2011). Greenhouse gas emission profiles of European livestock sectors. Anim. Feed Sci. Tech. 166, 16-28. doi: 10.1016/j.anifeedsci.2011.04.058

Lusk, J. L., and Norwood, F. B. (2011). Animal welfare economics. Appl. Econ. Perspect. Policy 33, 463-483. doi: 10.1093/aepp/ppr036

Macdiarmid, J. I., Douglas, F., and Campbell, J. (2016). Eating like there's no tomorrow: public awareness of the environmental impact of food and reluctance to eat less meat as part of a sustainable diet. Appetite 96, 487-493. doi: 10.1016/j.appet.2015.10.011

Marcoz, E. M., Melewar, T. C., and Dennis, C. (2014). The value of region of origin, producer and protected designation of origin label for visitors and locals: the case of Fontina cheese in Italy. Int. J. Tour. Res. 18, 236-250. doi: $10.1002 /$ jtr.2000

Martelli, G. (2009). Consumers' perception of farm animal welfare: an Italian and European perspective. Ital. J. Anim. Sci. 8, 31-41. doi: 10.4081/ijas. 2009.s1.31

Martínez Michel, L., Anders, S., and Wismer, W. V. (2011). Consumer preferences and willingness to pay for value-added chicken product attributes. J. Food Sci. 76, 469-S477. doi: 10.1111/j.1750-3841.2011.02354.x

Morgan, D. L. (1996). Focus groups. Annu. Rev. Sociol. 22, 129-142. doi: 10.1146/annurev.soc.22.1.129

Napolitano, F., Girolami, A., and Braghieri, A. (2010). Consumer liking and willingness to pay for high welfare animal-based products. Trends Food Sci. Tech. 21, 537-543. doi: 10.1016/j.tifs.2010.07.012

Nocella, G., Hubbard, L., and Scarpa, R. (2010). Farm animal welfare, consumer willingness to pay, and trust: results of a cross-national survey. Appl. Econ. Perspect. Policy 32, 275-297. doi: 10.1093/aepp/ppp009

Olynk, N. J. (2012). Assessing changing consumer preferences for livestock production processes. Anim. Front. 2, 32-38. doi: 10.2527/af.2012-0046

Padel, S., Zander, K., and Gössinger, K. (2010). "Regional production' and "fairness" in organic farming: evidence from a CORE organic project," in 9th European IFSA Symposium, eds I. Darnhofer and M. Grötzer (Vienna), 1793-1802.

Profeta, A., and Hamm, U. (2018). Consumers' expectations and willingness-topay for local animal products produced with local feed. Int. J. Food Sci. Tech. 54, 651-659. doi: 10.1111/ijfs.13933

Ripoll, G., Alberti, P., and Panea, B. (2015). Consumer segmentation based on food-related lifestyles and perception of chicken breast. Int. J. Poult. Sci. 14, 262-275. doi: 10.3923/ijps.2015.262.275

Rothgerber, H. (2012). Real men don't eat (vegetable) quiche: masculinity and the justification of meat consumption. Psychol. Men Mascul. 14, 363-375. doi: $10.1037 / \mathrm{a} 0030379$

Sato, P., Hötzel, M. J., and von Keyserlingk, M. A. G. (2017). American citizens' view of an ideal pig farm. Animals 7:64. doi: 10.3390/ani7080064

Spiller, A., Schulze, B., and Cordts, A. (2010). Was essen wir in zwanzig Jahren? DLG-Mitteilungen 1, 20-23.

Statista (2020). Fleischkonsum pro Kopf in Deutschland in den Jahren 1991 bis 2018. Available online at: https://de.statista.com/statistik/daten/studie/ 36573/umfrage/pro-kopf-verbrauch-von-fleisch-in-deutschland-seit-2000/ (accessed Feburary 20, 2020).

Statistisches Bundesamt (2021). Destatis online: 41322-0001: Geflügelstatistik. Geflügelschlachtereien, Geschlachtete Tiere. Available online at: https://wwwgenesis.destatis.de/genesis/online\#astructure (accessed January 14, 2021).

Te Velde, H., T., Aarts, N., and Van Woerkum, C. (2002). Dealing with ambivalence: farmers' and consumers' perceptions of animal welfare in livestock breeding. J. Agric. Environ. Ethics 15, 203-219. doi: 10.1023/A:1015012403331

Tonsor, G. T., Olynk, N., and Wolf, C. (2009). Consumer preferences for animal welfare attributes: the case of gestation crates. J. Agric. Appl. Econ. 41, 713-730. doi: $10.1017 /$ S1074070800003175

Tonsor, G. T., and Olynk, N. J. (2011). Impacts of animal well-being and welfare media on meat demand. J. Agric. Econ. 62, 59-72. doi: $10.1111 / j .1477-9552.2010 .00266 . x$

Van Poucke, E., Vanhonacker, F., Nijs, G., Braeckman, J., Verbeke, W., and Tuyttens, F. (2006). "Defining the concept of animal welfare: integrating the opinion of citizens and other stakeholders," in Proceedings of the 6th 
Congress of the European Society for Agricultural and Food Ethics (Wageningen: Wageningen Academic Publishers), 555-559.

Vanhonacker, F., and Verbeke, W. (2009). Buying higher welfare poultry products? Profiling Flemish consumers who do and do not. Poultry Sci. 88, 2702-2711. doi: $10.3382 /$ ps.2009-00259

Vanhonacker, F., and Verbeke, W. (2014). Public and consumer policies for higher welfare food products: challenges and opportunities. J. Agric. Environ. Ethics 27, 153-171. doi: 10.1007/s10806-013-9479-2

Vanhonacker, F., Verbeke, W., Van Poucke, E., and Tuyttens, F. A. M. (2008). Do citizens and farmers interpret the concept of farm animal welfare differently? Livest. Sci. 116, 126-136. doi: 10.1016/j.livsci.2007.09.017

Verbeke, W. A. J., and Viaene, J. (2000). Ethical challenges for livestock production: meeting consumer concerns about meat safety and animal welfare. J. Agric. Environ. Ethics 12, 141-151. doi: 10.1023/A:1009538613588

Vermeir, I., and Verbeke, W. (2006). Sustainable food consumption: exploring the consumer "attitude-behavioral intention" gap. J. Agric. Environ. Ethics 19, 169-194. doi: 10.1007/s10806-005-5485-3

Vigors, B. (2019). Citizens' and farmers' framing of "positive animal welfare" and the implications for framing positive welfare in communication. Animals 9:147. doi: 10.3390/ani9040147

Wägeli, S., Janssen, M., and Hamm, U. (2015). Organic consumers' preferences and willingness-to-pay for locally produced animal products. Int. J. Consum. Stud. 40, 357-367. doi: 10.1111/ijcs.12262

Weible, D., Christoph-Schulz, I., Salamon, P., and Zander, K. (2016). Citizens' perception of modern pig production in Germany: a mixed-method research approach. Br. Food J. 118, 2014-2032. doi: 10.1108/BFJ-12-2015-0458
Yang, R., Raper, K. C., and Lusk, J. L. (2009). "The impact of hormone use perception on consumer meat preference," in Proceedings of the Southern Agricultural Economics Association, United States of America, February 4-7, 2017 (Mobile).

Yue, C., and Tong, C. (2009). Organic or local? Investigating consumer preference for fresh produce using a choice experiment with real economic incentives. Hort Sci. 44, 366-371. doi: 10.21273/HORTSCI.4 4.2.366

Zepeda, L., and Leviten-Reid, C. (2004). Consumers' views on local food. J. Food Distrib. Res. 35, 1-6.

Zepeda, L., and Nie, C. (2012). What are the odds of being an organic or local food shopper? Multivariate analysis of US food shopper lifestyle segments. Agric Hum Values. (2012) 29:467-80. doi: 10.1007/s10460-012 9364-Z

Conflict of Interest: The authors declare that the research was conducted in the absence of any commercial or financial relationships that could be construed as a potential conflict of interest.

Copyright (c) 2021 Escobedo del Bosque, Risius, Spiller and Busch. This is an openaccess article distributed under the terms of the Creative Commons Attribution License (CC BY). The use, distribution or reproduction in other forums is permitted, provided the original author(s) and the copyright owner(s) are credited and that the original publication in this journal is cited, in accordance with accepted academic practice. No use, distribution or reproduction is permitted which does not comply with these terms. 